\title{
The expressiveness in the assessment of the voice professionals communication: a literature review
}

Telma Dias dos Santos ${ }^{1}$ https://orcid.org/0000-0002-8955-7707

Léslie Piccolotto Ferreira ${ }^{1}$ https://orcid.org/0000-0002-3230-7248

Pontifícia Universidade Católica de São Paulo - PUC SP, São Paulo (SP), Brasil. Research support source: CAPES.

Conflict of interests: Nonexistent

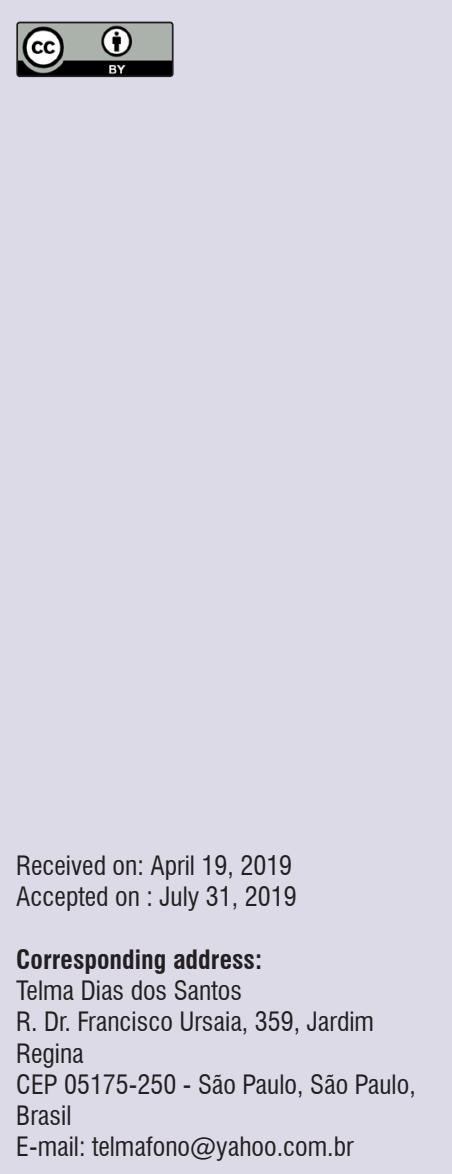

\section{ABSTRACT}

Purpose: to identify, through a critical review of the literature, what are the instruments used to assess the expressiveness of voice professionals and what are the parameters addressed in these instruments.

Methods: a literature search was carried out on four platforms: Scopus, Science Direct, SAGE Journals and Medline. The search considered the period from 2006 to 2016 and original articles, theses, dissertations and specialization monographs were considered to compose the sample.

Results: 5,295 productions were found in the four databases. Of these, after the filters by title of the production, evaluation of the summary, and content of the article, there were 39 articles with thematic expressiveness and voice professionals of which only seven presented some type of speech-language evaluation instrument that approached expressiveness.

Conclusion: five studies presented their instruments in their entirety and of these, two were published in national journals, and none of them were validated. When the expressivity parameters are mentioned, those registered in greater numbers are those related to oral expressiveness. The parameters of nonverbal expressivity are still timid, with the predominant use of three variables, namely facial expression, gestures and posture.

Keywords: Communication; Voice; Speech, Language and Hearing Sciences; Evaluation Studies 


\section{INTRODUCTION}

As in other areas of health, speech-language pathology was initially established with a predominance of individual care, developed in offices and clinics. With the inclusion of speech-language pathologists in collective contexts in the 1990s, the speech-language pathology included prevention and, thus extended the scope for vocal enhancement ${ }^{1}$. Thus, the work with voice professionals began related to vocal complaints, specially vocal rehabilitation, and the field expanded with the advisory work ${ }^{2}$, communication improvement and improvement related to the expressiveness ${ }^{3}$.

The expressiveness has been present in the routine of speech-language pathology in Brazil for a long time. Although shyly, the literature in the 1970s had studies on expressiveness aimed initially at working with the oral expressiveness (voice and speech) of voice professionals. The publication of papers that address the gesture and role of the body in expressiveness began to emerge from the 2000s, a period in which the speech-language pathology began to seek different theoretical references as a starting point ${ }^{4}$. This moment indicates the approach to linguistics, which is essential to understand the relationship between the sound and the meaning of the voice ${ }^{5,6}$. Vocal expression, vocal expressiveness, oral expressiveness, and speech expressiveness are some commonly used terms.

From the speech-language pathology perspective, working with expressiveness means acting in an integrated way with verbal communication - verbal expressiveness (textual content), with vocal resources - vocal/oral expressiveness (voice, articulation, modulation, speech rate, pitch, loudness, resonance, prosody) and with non-verbal communication non-verbal expressiveness (gestures and facial expression $)^{2,7}$.

Recently, the term 'expressiveness' has also been used as a synonym for communication and expression of emotions. With regard to the communicative effects, there is a formative and compositional dimension of communication that is capable of working as an element of spontaneity, and authenticity that is strictly related to expressiveness ${ }^{7}$. The association of the term 'expressiveness' with questions related to emotions is linked to the attribution of positive (joy, confidence, dynamism and credibility, for example) and negative (insecurity, weakness, childishness, falsehood and artificiality, for example) characteristics to speech ${ }^{5}$. Therefore, emotional expressiveness can be understood as the behavioral changes that follow emotions; verbal or nonverbal behaviors of emotional experience; and external expression of emotions ${ }^{8}$. It has an action potential in the construction, deconstruction, and reconstruction of a speech ${ }^{7}$, it also seeks an interactivity between body, verbal, vocal ${ }^{3}$ and emotional ${ }^{8}$ resources and creates a natural colloquiality that reflects a particular time of expression. In short: it poses a challenge for speech-language pathology.

Authors report ${ }^{9}$ that the great number of publications on expressiveness and journalism professionals is inversely proportional to the number of studies on expressiveness with other voice professionals. The authors also highlight the predominance of the use of instruments for the assessment of expressiveness, which were designed by the researchers themselves, but are not validated.

From these considerations, it is important to know how the expressiveness of different voice professionals is discussed and evaluated in speech-language pathology research, thus mapping the research on expressiveness of voice professionals.

Thus, this study aims to identify, through a critical review of the literature, what are the instruments used to assess the expressiveness of voice professionals and what are the parameters addressed in these instruments.

\section{METHODS}

This is a descriptive and exploratory research. The following platforms were selected as sources for data collection: Scopus, Science Direct, SAGE Journals and Medline. These databases were selected based on three criteria: the number of relevant journals in them; the potential reach of publications; and the presence of journals from the main areas of interdisciplinarity and the relevance for the research topic, namely Health, Speech-Language Pathology, Psychology, Linguistics and Communication.

The keywords selected to guide the search were: 'expressividade' and 'voz profissional' or 'fonoaudiologia', as well as 'comunicação verbal' and 'voz profissional' or 'fonoaudiologia' in Portuguese and 'expressivity' and 'professional voice' or 'speech therapist', as well as 'non-verbal communication' and 'professional voice' or 'speech therapist'; and 'expressiveness' and 'professional voice' or 'speech-language pathology' in English.

Regarding the type of bibliographic source, original articles, theses, dissertations and specialization monographs were considered to compose the sample. 
The search was conducted between April 02, 2017 and May 07, 2017, and considered the period from 2006 to 2016.

The findings were categorized and analyzed according to: journal, area of knowledge, type of study (literature review, observational or interventional), study participants (voice professionals) and assessment instruments used.

In total, 5,295 productions were found in the four databases. Duplicated materials were excluded after the initial filter, by the production title, that is, when the same production was found two or more times in the same database or in others. A second filter, which still considered the production title, excluded results that were not related to the subject of research. After the assessment, there were 39 articles remaining that were related to expressiveness and professional voice (Figure 1). Of these, 36 were selected after critical reading of articles (Appendix 1 ).

The results indicate a larger number of publications on this topic between 2013 and 2015, with 15 national and international productions during this period (Figure 2).

Among the 36 studies related to expressiveness and voice professionals, 26 address TV professionals as research subjects and 11 discuss some type of intervention (Figure 3).

Nine studies had some type of instrument to assess the subject's expressiveness, communication or voice. Among the seven studies that used their own instruments that were developed during the research, two had teachers as study subjects, one was aimed at undergraduate students, and four were interventional studies with television journalists (Figure 2). Five papers included the presentation of their instruments in full, one of which was used to characterize the voice of teachers of a Social Communication course and the other four were used for intervention with journalism professionals. None of the five instruments was validated in the literature. Of these instruments, one used multiple choice questions, while three used multiple choice questions and also the Visual Analogue Scale (VAS) as a measurement unit, and another used multiple choice questions and also descriptive questions (Figure 4).

The five instruments include items related to oral, speech and non-verbal expressiveness in their assessment. Emotional and interpretation aspects were included in only one. Three non-verbal communication aspects are present in all instruments: posture, facial expression and gestures (Figure 5).

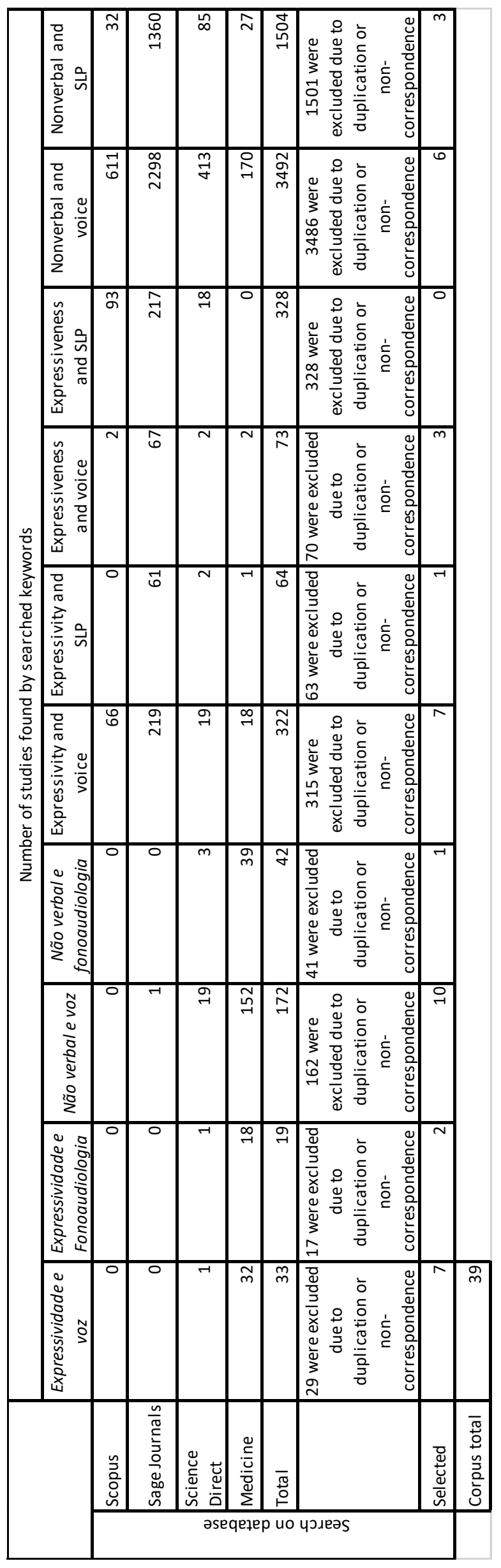




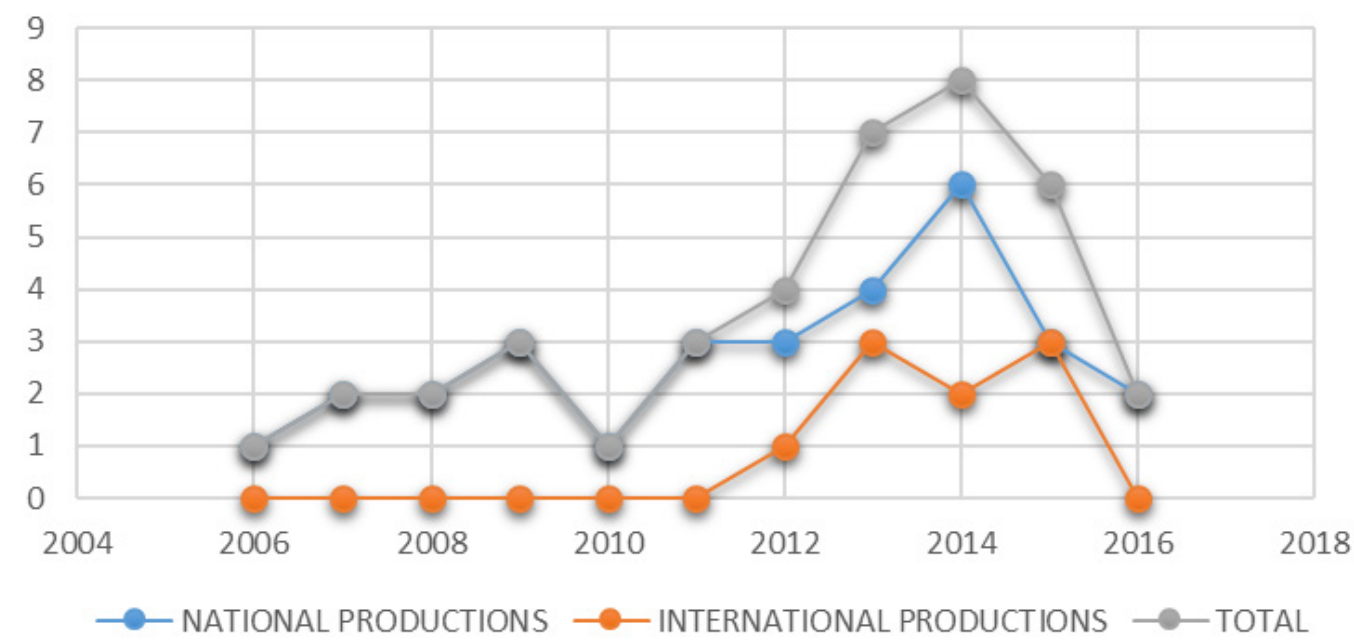

Figure 2. Total productions found on expressiveness and/or voice professionals

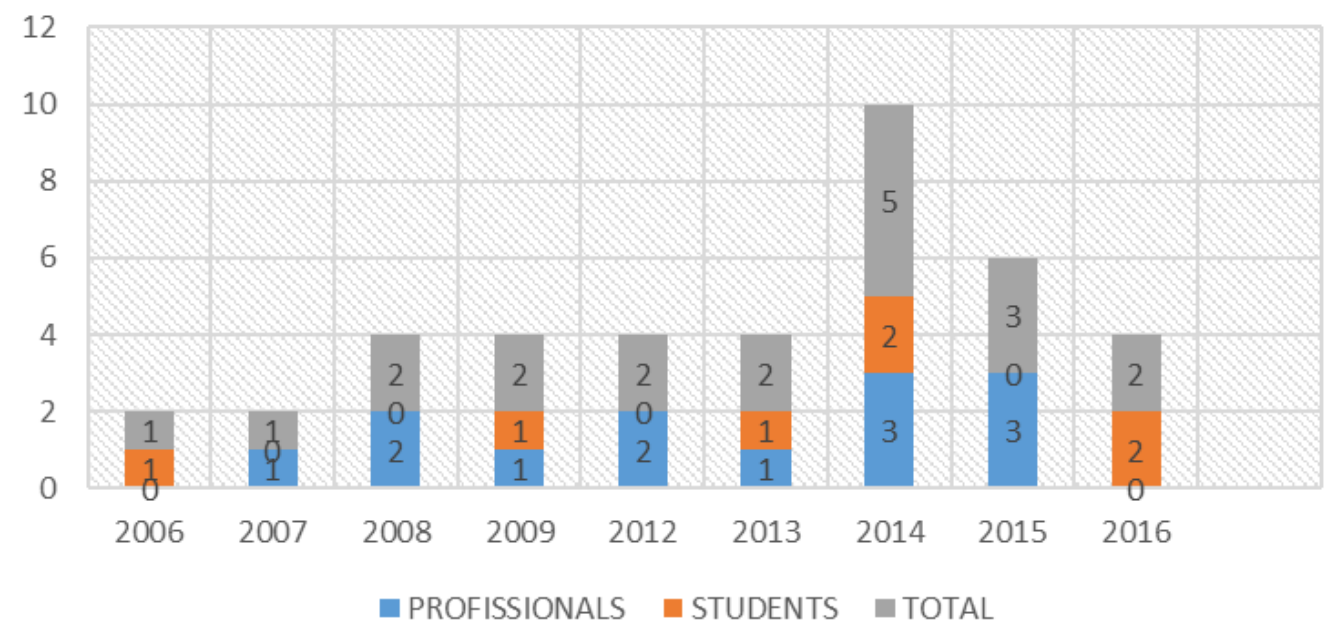

Figure 3. Number of productions by research subjects and per year on expressiveness and/or voice professionals

\begin{tabular}{|c|c|c|c|}
\hline YEAR & AUTHOR & TOPICS & MEASUREMENT \\
\hline 2006 & Vieira VP & Multiple Choice & Visual Analogue Scale \\
\hline 2008 & Trindade LLM & Multiple Choice + Descriptive & - \\
\hline 2014 & Andrade et al. & Multiple Choice & - \\
\hline 2015 & Santos TD & Multiple Choice & Visual Analogue Scale \\
\hline 2016 & Santos TD & Multiple Choice & - \\
\hline
\end{tabular}

Figure 4. Description of the pre- and post-intervention assessment instruments according to type of questions and measurement 


\begin{tabular}{|c|c|c|c|c|}
\hline VIEIRA 2006 & TRINDADE 2008 & ANDRADE et al 2014 & SANTOS 2015 & SANTOS 2016 \\
\hline Visual inspection & $\begin{array}{l}\text { Speech-language } \\
\text { pathology protocol }\end{array}$ & $\begin{array}{l}\text { Voice assessment and } \\
\text { speech fluency script }\end{array}$ & $\begin{array}{l}\text { Performance analysis } \\
\text { and degree of } \\
\text { naturalness }\end{array}$ & Body aspects \\
\hline $\begin{array}{l}\text { Proper posture to the } \\
\text { speech function }\end{array}$ & Vocal quality & $\begin{array}{l}\text { Connected speech } \\
\text { assessment }\end{array}$ & $\begin{array}{c}\text { The report became } \\
\text { clearer }\end{array}$ & Facial expression \\
\hline $\begin{array}{c}\text { Gestures appropriate to } \\
\text { the text }\end{array}$ & Resonance & $\begin{array}{l}\text { Singing voice } \\
\text { assessment }\end{array}$ & $\begin{array}{c}\text { The reporter presents the } \\
\text { news naturally }\end{array}$ & Body posture \\
\hline $\begin{array}{c}\text { Facial expression } \\
\text { appropriate to the text }\end{array}$ & Pitch & $\begin{array}{l}\text { Maximum Phonation } \\
\text { Time (MFT) }\end{array}$ & $\begin{array}{l}\text { The reporter talks better } \\
\text { with the viewer }\end{array}$ & Body movements \\
\hline \multirow[t]{2}{*}{ Sound articulation } & Loudness & Voice type & $\begin{array}{l}\text { The reporter gives more } \\
\text { confidence in speaking }\end{array}$ & Head movements \\
\hline & Speed & Resonance & $\begin{array}{c}\text { The reporter is } \\
\text { convincing }\end{array}$ & Use of gestures \\
\hline Auditory analysis & CPFA & Pitch & $\begin{array}{l}\text { You feel more involved in } \\
\text { the news }\end{array}$ & Look \\
\hline Adequate vocal quality & Vocal attack & Loudness & & Clothing \\
\hline $\begin{array}{l}\text { Pitch appropriate to the } \\
\text { text }\end{array}$ & Emphasis & Vocal attack & Visual inspection & \\
\hline Appropriate speech rate & Pauses & Types of breathing & $\begin{array}{l}\text { Proper posture to the } \\
\text { speech function }\end{array}$ & Speech aspects \\
\hline $\begin{array}{c}\text { Pauses appropriate to } \\
\text { the text }\end{array}$ & Melodic curve & Articulation & $\begin{array}{c}\text { Gestures appropriate to } \\
\text { the text }\end{array}$ & Speech rate \\
\hline \multirow[t]{14}{*}{$\begin{array}{c}\text { Emphasis appropriate to } \\
\text { the text }\end{array}$} & Rate & CPFA & $\begin{array}{c}\text { Facial expression } \\
\text { appropriate to the text }\end{array}$ & Articulation/diction \\
\hline & Facial expression & Speech rate & Sound articulation & Use of pauses \\
\hline & Body posture & Speech rate & & Clarity/intelligibility \\
\hline & Use of gestures & & Auditory analysis & Voice \\
\hline & Head movement & Prosodic features & Adequate vocal quality & $\begin{array}{l}\text { Emphases used during } \\
\text { speech }\end{array}$ \\
\hline & & Emphasis & $\begin{array}{c}\text { Pitch appropriate to the } \\
\text { text }\end{array}$ & \\
\hline & & Intonation & Appropriate speech rate & $\begin{array}{c}\text { Emotional and } \\
\text { interpretation aspects }\end{array}$ \\
\hline & & & $\begin{array}{c}\text { Pauses appropriate to } \\
\text { the text }\end{array}$ & More natural \\
\hline & & Body assessment & $\begin{array}{c}\text { Emphasis appropriate to } \\
\text { the text }\end{array}$ & More self-assured \\
\hline & & Gestures & & More friendly \\
\hline & & Facial expression & & More interesting \\
\hline & & Eyes & & More enjoyable \\
\hline & & & & More confident \\
\hline & & & & More charismatic \\
\hline
\end{tabular}

Figure 5. Description of the items found in each instrument according to the classification of the authors 


\section{LITERATURE REVIEW}

Instruments for evaluation and reassessment are traditionally used in speech-language pathology, especially in rehabilitation. There are several assessment and self-assessment instruments validated for Portuguese language in this area, for example. The fact that these validated instruments are directed to the voice clinic may explain the non-tradition of using instruments to evaluate voice, communication, and adapted expressiveness of the voice professional, that is, the demand assessment of customers who need speech-language pathology, vocal enhancement, or communicative qualification. Only two of the 39 studies in this research used a validated instrument. A paper from the Universidade de Sergipe in $2014^{10}$ used the Consensus Auditory-Perceptual Evaluation of Voice (CAPE-V) instruments to characterize the voice of communication students at the university. It is noteworthy that this instrument was not designed for expressiveness assessment, but rather for use in clinical and research on vocal rehabilitation. In addition to its own instrument (which was not described in the paper), the Kingdomality ${ }^{\circledR}$ test was used in another article from 2015'11, which aimed to analyze the perceptive and acoustic aspects of speech expressiveness in executive managers to assess the personality of these speakers. Therefore, this research indicates that there is no validated instrument that can be used to assess the expressiveness.

Of the seven studies that described the use of their own instruments to assess voice or expressiveness, four evaluated the expressiveness of TV journalism professionals. A study conducted with teachers presented an instrument designed and used to characterize the voice of communication students, while two others - both articles from national journals - are interesting because they describe the process of voice and expressiveness assessment, but do not present any specific evaluation instrument. (Figure 2). From this survey, it is possible to notice a lack of consensus regarding the expressiveness measurement variables ${ }^{5,12,13}$, especially regarding the axes of expressiveness (vocal/oral, verbal, nonverbal and emotional). The research also indicates the lack of validated assessment instruments that address the expressiveness of voice professionals. Only two of the five papers that presented their instruments in full were published in national journals, the others were recorded in master's dissertations (2) and the last, a specialization monograph (Figure 2).
The communication qualification work has been extensively explored by speech-language pathology in recent years. It has been addressed in particular by speech-language pathologists that are voice specialists. It is not uncommon to find the terms communicative parameters and expressiveness as synonyms in the same speech-language pathology study with voice professionals, whether in a descriptive or intervention study. Most of these studies only evaluate oral parameters. One of these papers, from 2008, discusses the terms used by speech-language pathology in its history, as well as their convergences and divergences, and reports the trend to approach oral expression in a fragmented way and to divide the speech, voice and language parameters in studies on expressiveness. Most studies associate voice and speech parameters within oral expressiveness, as suggested by the authors. In addition, speech parameters are recorded in greater numbers when compared to voice parameters. Regarding vocal parameters, all instruments tend to have a lower rating on voice quality, pitch and loudness. Similar data were reported by a study ${ }^{5}$ that analyzed 10 book chapters and 13 dissertations or theses by Brazilian authors. This reduction may be explained by the vocal condition of the research subjects in these cases, who do not present vocal changes and, therefore, would not require thorough vocal evaluation. The authors also reported that all studies used the auditory-perceptual assessment, but not all use the perceptual-visual assessment. The most frequent items in the auditory-perceptual evaluation were: vocal quality, resonance, pitch and loudness and their variations, pauses, segment duration; speed (or speech and articulation rate); rate, articulation; accent and fluency. It is possible to relate the predominance of items on oral expressiveness from the association of speech-language pathology with phonetics. Parameters such as vocal quality, pace, modulation, pauses and emphases, are closely related to the sound and meaning of the word ${ }^{14}$ and have an expressive particularity.

Emphasis facilitates speech understanding, that is, the relative prominence that highlights certain syllables of words in speech flow ${ }^{15}$. This accent contains syntactic, prosodic, and communicative information. The results from the study of prosodic factors, more specifically on intonation, are crucial for understanding how different modalities and meaning effects are expressed from the same sequence of segments in natural speech ${ }^{14}$. 
With respect to the communication advisory works of spoken voice professionals, expressiveness has been approached more often in publications on the speech-language pathology work with television journalism professionals. The number of publications related to this work conducted by a speech-language pathologist increased in the same extent as the actions with these professionals. Some studies ${ }^{3,16,17}$ provide an interface between speech-language pathology and television journalism, especially contents that show the importance of the work with expressiveness in this environment. In short, these professionals work with their image, and they use their voices, bodies, and communication as a working tool ${ }^{18}$, which is one of the reasons for the special attention given by speech-language pathology to the qualification of these professionals. It is noteworthy that the instruments did not address verbal communication, among the topics on expressiveness, in any of the studies with television journalists. Most instruments focus on vocal aspects ${ }^{19-23}$, or address expressiveness regarding vocal and speech parameters ${ }^{24,25}$. It is worth discussing the changes that verbal communication in television journalism has faced in this new television scenario and the role of the speech-language pathologist in face of this demand. Journalism is a particular discursive genre whose characteristics need to be recognized, validated and shared by the individuals involved ${ }^{26}$. This means that the operation of journalistic speech relies heavily on the enrollment of subjects (vehicles, advertisers, journalists, contributors, sources and readers). The analysis and interpretation of television news programs involve the consideration of historical, social, ideological and cultural aspects of television journalism at the same time ${ }^{26}$. Today, much of contemporary television programs are designed around conversation. Verbal aspects are relevant, as the identity is established from the discursive strategies that are used to create a bond with the viewer ${ }^{18}$.

Similarly, there are still few scientific studies that show a more careful look at the non-verbal aspect $3,9,27,28$ and there seems to be no speech-language pathology production that addresses changes in the verbal communication of voice professionals. A study ${ }^{29}$ that discusses body aspects in the television journalist performance in face of the new demands reports that credibility, timeliness and empathy are three values in the meaning production process that become significant from details related to the environment, distance and proximity relationships, appearances, body movements and speech features. Also according to the author, empathy, in particular, is one of the non-verbal codes that indicates that presenters are 'people like us', that is, that they act and react in the same way as the viewer in certain situations. By dealing with the specificity of professional communication in a unique way, these reflections deserve to be extended to other voice professionals.

The growing number of international studies on speech-language pathology and media professionals confirms the prevalence of publications on expressiveness with television journalists revealed in this review. A milestone for the communicative qualification in the speech-language pathology. A recent study discusses the role of the eyebrow as a communicative, expressive and engaging resource for news presentation $^{30}$ and explores the eyebrow movement as an expressive marker in the news presentation of 81 television presenters. According to the authors, eyebrow movements are a feature that plays an important role in understanding the attitudes or positioning of television journalists regarding the news. The authors report that the style of news presentation has changed to a 'talk' in Western news programs. They also highlight that the television news production occurs in a multidirectional process as a discursive practice. According to the authors, when conveying emotion, expressiveness manifests itself through different verbal and especially non-verbal expressive behaviors. International studies on speech-language pathology intervention with journalism professionals are still new, but there is a Spanish study ${ }^{31}$, which describes a speech-language pathology intervention with journalism students, that vocal quality, that deserves attention, since it includes breathing, vocal projection, body posture, and prosody as expressiveness resources.

Non-verbal communication was present in the five instruments found, but only one study assessed the body parameters more broadly, with the number of parameters being equal to those measured in speech and voice. In the other studies, the non-verbal communication parameters addressed three main items: facial expression, gestures and posture. Despite the significant number of articles in Brazilian journals of SpeechLanguage Pathology, the descriptions and analyzes of non-verbal communication are still shy when compared to those of oral and vocal expressiveness. ${ }^{9}$. There are few studies that include the non-verbal communication of voice professionals or that relate voice and non-verbal communication in the communication 
process $^{9}$. A systematic review on non-verbal behavior and workplace communication also points to the fact that non-verbal behavior and its communicative properties have not been entirely disregarded in scientific productions, but that the progress on non-verbal behavior research occurred more slowly ${ }^{32}$.

It is worth mentioning the chapter of the SpeechLanguage Pathology Treaty of 2004 for publishing a speech-language assessment instrument for TV presenters and reporters that covers voice, speech and body aspects ${ }^{16}$. It is intriguing that none of the sources in this literature review mentioned such publication.

Another study worth mentioning ${ }^{33}$, and that was not included in the survey, since it was presented and published in the annals of The Voice Foundation's $45^{\text {th }}$ Annual Symposium: Care of the Professional Voice, is a research, from a broad perspective, which proposes an instrument for evaluating television communicative competence, aimed at the TV audience, which can be applied by TV professionals and speech-language pathologists. This instrument addresses in a very practical way, the overall impact of oral communication (from the perspective of planning and fluency that encompasses body and emotional expressiveness), voice and speech assessment (oral expressiveness) and cognitive skills (verbal expressiveness). Above all, it is an interesting instrument for addressing expressiveness in its different dimensions.

Three of the five instruments analyzed presented questions on the interpretation of the news, that is, questions that seek to understand the meaning of what was said through the opinion/feeling of the researcher regarding the communicative performance. It is essential to know the story, which story to tell, how to tell it, and to whom, but consciously using its expressive instruments, especially emotional and body ${ }^{34}$, is also critical for any communicating professional. Therefore, the work on expressiveness should not be restricted to the instrumentalization of communication?.

The literature review made it clear that there is no consensus between the parameters used for the speech-language pathology assessment of voice professionals. Few studies present the instruments used for the assessment and there are still few published studies that evaluate expressiveness in a broader way, which simultaneously considers the vocal, verbal, non-verbal and emotional aspects. None of these publications has analyzed the validation process of an expressiveness assessment instrument, which, in fact, seems to be a difficult task considering the need to include complex and subjective issues inherent in the communicative process and expressiveness.

Thus, the idea of creating a script for the assessment of expressiveness that can cover the plurality of expressiveness and the specificity of each voice professional assisted seems interesting and a priority at a time when the speech-language pathologist is increasingly required to meet the demands of this nature.

\section{CONCLUSION}

Among the 5,295 literature sources addressed, only 39 discussed the expressiveness of the voice professional, and only five of them have assessment instruments. Of these, only two were published in full, in national journals. When the expressivity parameters are mentioned, those registered in greater numbers are those related to oral expressiveness. The parameters of non-verbal expressivity are still timid, with the predominant use of three variables, namely facial expression, gestures and posture.

\section{REFERENCES}

1. Chun RYS, Servilha EAM, Santos LAM, Sanches MH. Promoção da saúde: o conhecimento do aluno de jornalismo sobre sua voz. Distúrb. Comum. 2007; 19(1):73-80.

2. Ferreira LP. Assessoria fonoaudiológica aos profissionais da voz. In: Fernandes FDM, Mendes BCA, Navas ALPGP (orgs). Tratado de Fonoaudiologia. São Paulo: Ed Roca; 2010. p.746-53.

3. Cotes CSG. O estudo dos gestos vocais e corporais no telejornalismo brasileiro [tese]. São Paulo (SP): Pontifícia Universidade Católica de São Paulo; 2008.

4. Ferreira LP. Expressividade - A trajetória da Fonoaudiologia Brasileira. In: Kyrillos L (org). Expressividade: da teoria à prática. Rio de Janeiro: Revinter; 2005. p. 1-14.

5. Viola IC, Ferreira LP. A avaliação da expressividade oral e corporal. XVI Seminário de Voz da PUC-SP; jun 2007; Pontifícia Universidade Católica de São Paulo. São Paulo, São Paulo, Brasil.

6. Viola IC. Breve histórico dos estudos sobre expressividade e questões terminológicas. XVIII Seminário de Voz da PUC-SP; jun, 2008; São Paulo, São Paulo, Brasil.

7. Penteado RZ, Pechula MR. Expressividade em jornalismo: interfaces entre Comunicação, 
Fonoaudiologia e Educação. Intercom, Rev. Bras. Ciênc. Comun. 2018; 41(1):153-66.

8. Dinis A, Gouveia JP, Xavier A. Estudo das características psicométricas da versão portuguesa da escala de expressividade emocional. Psycologica - Avaliação Psicológica em Contexto Clínico. 2011;54:111-38.

9. Santos TD, Andrada e Silva M. Voice professionals' non-verbal communication: what has it been researching in speech language pathology? Rev. CEFAC. 2016;18(6):1447-55.

10. Andrade BMR, Nascimento LS, Passos CRS, Nascimento UN, Souza GGA, Santos TC et al. Vocal characterization of the students of the Department of Social Communication of the Federal University of Sergipe. Distúrb. Comum. 2014;26(4):752-68.

11. Marquezin DMSS, Viola I, Ghirardi ACAM, Madureira S, Ferreira LP. Executives' speech expressiveness: analysis of perceptive and acoustic aspects of vocal dynamics. CoDAS. 2015;27(2):160-9.

12. Santos TD, Pedrosa V, Behlau M. Comparison of virtual and present speech voice therapist service in television journalism professional. Rev. CEFAC. 2015;17(2):385-95.

13. Vale MC. Avaliação da expressividade oral: análise segundo perspectiva do fonoaudiólogo brasileiro [dissertação]. São Paulo (SP): Pontifícia Universidade Católica de São Paulo; 2016.

14. Fontes MAS, Madureira S. Gestural prosody and the expression of emotions: a perceptual and acoustic experiment. In: Proceedings of the 18th International Congress of Phonetic Sciences; University of Glasgow; Glasgow; 2015.

15. Madureira S. Intonation and variation: the multiciplicity of forms and senses. Revistes Catalanes amb Accés Obert (RACO). 2016;Special issue(6):57-74.

16. Kyrillos LCR. Voz na midia (televisao e Radio). In: Ferreira LP, Lopes DM, Limongi SCO (orgs). Tratado de Fonoaudiologia. Sao Paulo: Roca; 2004. p.150-65.

17. Gama ACC, Kyrillos LR, Feijó D. Relatos do IV Encontro Nacional de Fonoaudiologia da Central Globo de Jornalismo. Rio de Janeiro: Revinter: 2005.

18. Cotes CSG. O uso das pausas nos diferentes estilos de TV. Rev. CEFAC. 2007;9(2):228-37.

19. Penteado RZ, Pechula MR. Expressividade na formação de jornalistas: contribuições da fonoaudiologia no contexto educacional. Revista Latino-americana de Jornalismo. 2017;4(2):131-51.

20. Cielo CA, Morisso MF, Contero G. Hábitos e queixa vocais de estudantes de comunicação. Salusvita. 2009;28(2):169-81.

21. Caldeira CRP, Vieira VP, Behlau M. Análise das modificações vocais de repórteres na situação de ruído. Rev. Soc. Bras. Fonoaudiol. 2012;17(3):321-6.

22. Lopes LW, Lima ILB, Silva EG, Almeida LNA, Almeida AAF. Accent and television journalism: evidence for the practice of speech language pathologists and audiologists. CoDAS. 2013;25(5):475-81.

23. Santos A, Leal A, Pereira EC, Marcolino J, Dassie-Leite AP. Self-perception and voice quality of journalism students. Rev. CEFAC. 2014;16(1):566-72.

24. Constantini AC. Mudanças na estruturação prosódica de texto jornalístico antes e após intervenção fonoaudiológica. J Speech Sciences. 2012;2(2):23-42.

25. Neiva TMA, Gama ACC, Teixeira LC. Vocal and body expressiveness to speak well in telejournalism: training results. Rev. CEFAC. 2016;18(2):498-507.

26. Gomes IMM. Metodologia de análise de telejornalismo. In: Gomes IMM (org). Gêneros televisivos e modos de endereçamento no telejornalismo. Salvador: EDUFBA, 2011. p. 17-47.

27. Silva EC, Penteado RZ. Characteristics of innovations in television journalism and the expressiveness of the anchor. Audiol Commun Res. 2014;19(1):61-8.

28. Penteado RZ, Gastaldello LM, Silva EC. Changes in television sports journalism and the effects on the expressivity: a study of the vocal and non- verbal resources of the anchors in the "Globo Esporte" tv show. Disturb. Comunic. 2014;26(3):482-92.

29. Cavenaghi B. Telejornalismo local: estratégias discursivas e a configuração do telespectador [Dissertação]. Florianópolis (SC): Universidade Federal de Santa Catarina; 2013.

30. Han Z, Zhu H. Stance markers in television news presentation: expressivity of eyebrow flashes in the delivery of news. Semiotica. 2018;221:279-300.

31. Rodero E, Diaz-Rodriguez C, Olatz L. A training model for improving journalists' voice. J Voice. 2018;32(2):386.e11-386.e19.

32. Bonaccio S, O'Reilly J, O'Sullivan SL, Chiocchio F. Nonverbal behavior and communication in the 
workplace: a review and a agenda for research. Journal Managem. ent. 2016;42(5):1044-74.

33. Franco EM, Panico A, Rolim MR, Stier MA, Feijó D. Newscast Communication Protocol. The Voice Foundation's 45th Annual Symposium: Care of the
Professional Voice. 1-5 junho de 2016. Philadelphia PA - EUA.

34. de Gelder B. Towards the neurobiology of emotional body language. Nat Rev. Neurosci. 2006;7(3):242-9. 


\begin{tabular}{|c|c|c|c|c|c|c|c|c|c|c|}
\hline 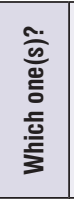 & 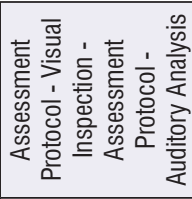 & & & & 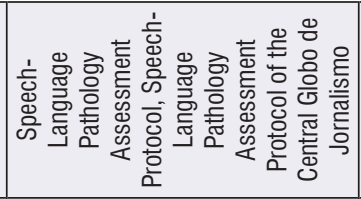 & & & & & \\
\hline 忘 & $\stackrel{\mathscr{C}}{=}$ & z & $\stackrel{2}{2}$ & $\stackrel{2}{2}$ & $\stackrel{\mathscr{J}}{x}$ & $\stackrel{2}{2}$ & q & \& & zo & z \\
\hline 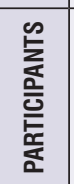 & $\frac{\frac{S}{1}}{\frac{7}{q}}$ & $\frac{\text { 号 }}{\frac{\bar{z}}{\mathbf{c}}}$ & $\frac{\frac{9}{7}}{\frac{\bar{z}}{4}}$ & $\frac{2}{\frac{2}{2}}$ & 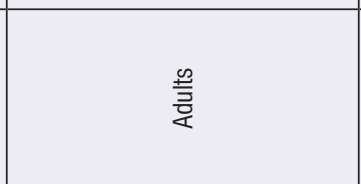 & $\frac{\frac{9}{7}}{\frac{\bar{z}}{4}}$ & $\frac{\infty}{\frac{5}{z}}$ & $\frac{\text { 号 }}{\frac{\bar{z}}{\mathbf{x}}}$ & $\frac{\text { s. }}{\frac{3}{q}}$ & $\frac{\text { 号 }}{\frac{7}{q}}$ \\
\hline 富 & 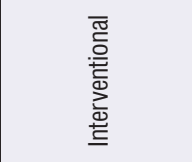 & 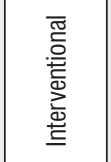 & 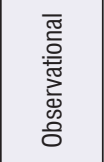 & 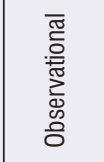 & 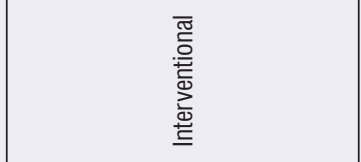 & 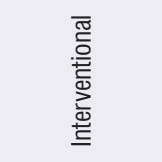 & 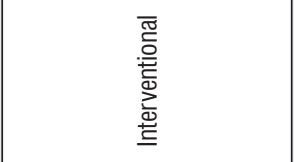 & 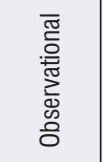 & 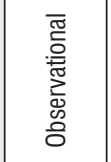 & 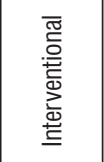 \\
\hline 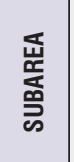 & 苂 & 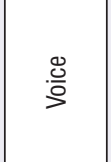 & $\stackrel{\ddot{\circ}}{\frac{\ddot{s}}{3}}$ & 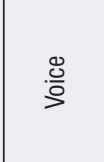 & 䒕 & 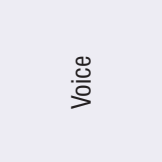 & 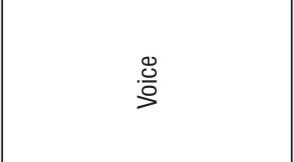 & $\stackrel{\circ}{\circ}$ & $\stackrel{.0}{\circ}$ & . \\
\hline 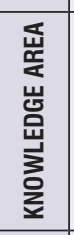 & 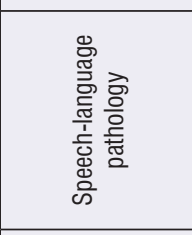 & 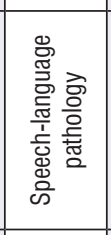 & 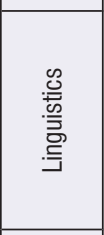 & 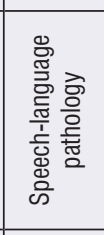 & 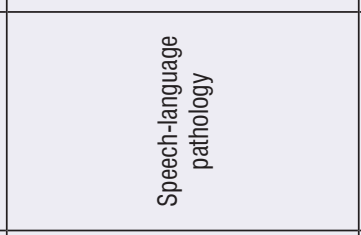 & 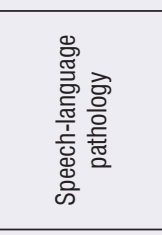 & 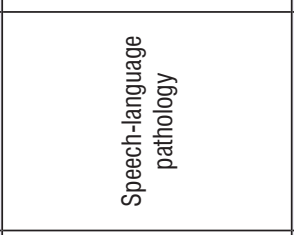 & 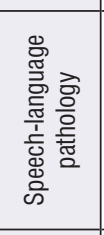 & 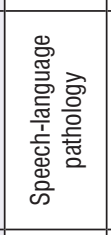 & 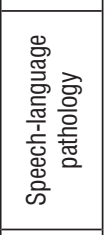 \\
\hline 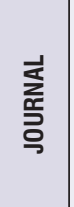 & 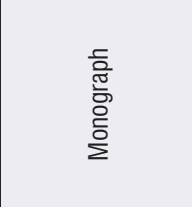 & 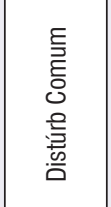 & 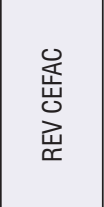 & $\begin{array}{l}\frac{\infty}{\omega 0} \\
\frac{\Phi}{F}\end{array}$ & 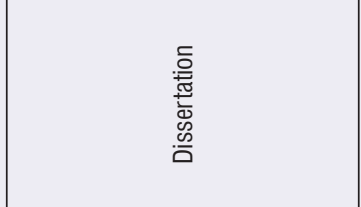 & 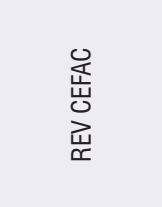 & $\begin{array}{l}\text { 缹 } \\
\text { 亗 }\end{array}$ & 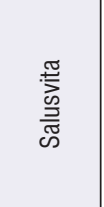 & 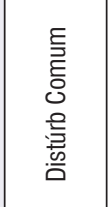 & 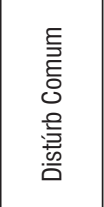 \\
\hline $\begin{array}{l}\text { zo } \\
\text { 㫐 } \\
\text { 总 } \\
\stackrel{\text { I }}{\Xi}\end{array}$ & 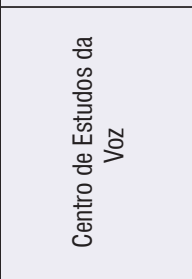 & 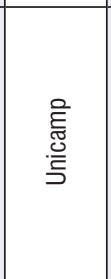 & 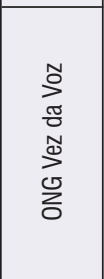 & 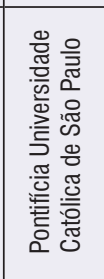 & 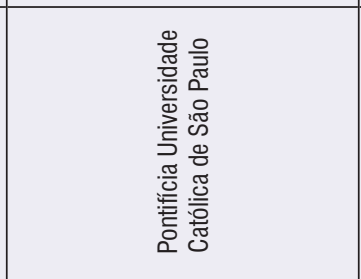 & 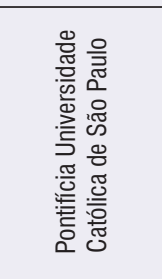 & 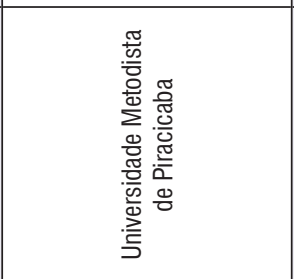 & 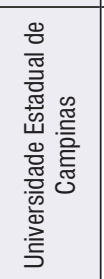 & 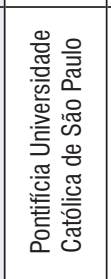 & 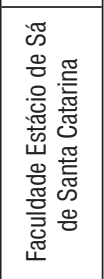 \\
\hline 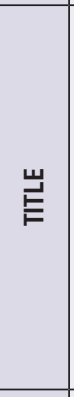 & 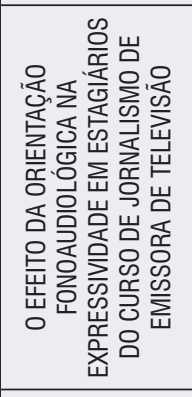 & 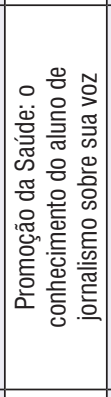 & 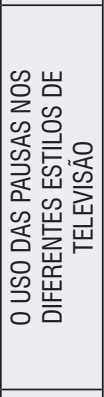 & 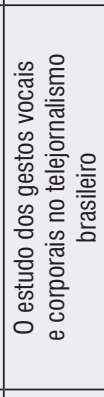 & 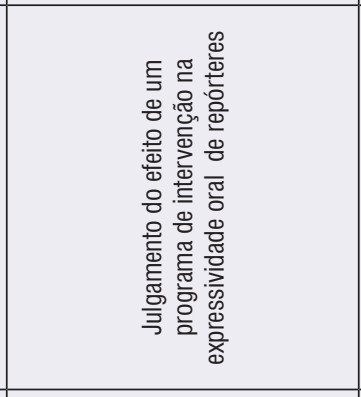 & 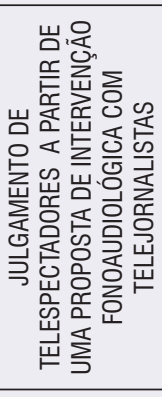 & 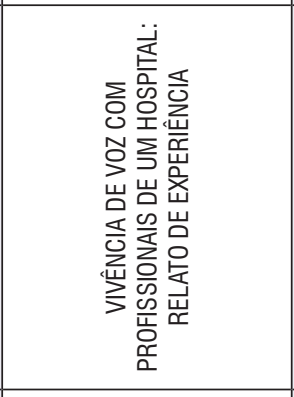 & 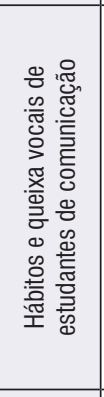 & 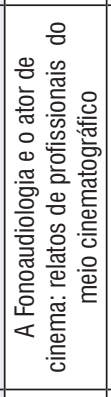 & 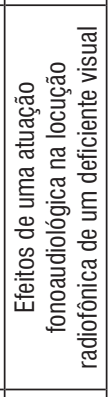 \\
\hline 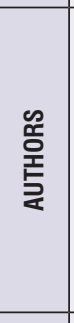 & 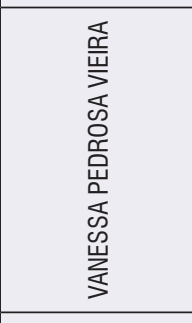 & 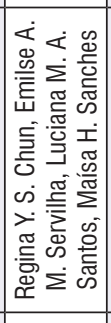 & $\begin{array}{l}\mathscr{0} \\
\frac{0}{0} \\
0 \\
\frac{\pi}{5} \\
\frac{\pi}{0} \\
\frac{\pi}{0}\end{array}$ & $\begin{array}{l}\mathscr{0} \\
\frac{0}{0} \\
0 \\
\frac{\pi}{5} \\
\frac{\pi}{0} \\
0\end{array}$ & 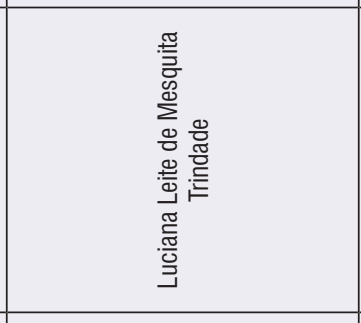 & 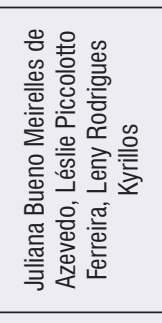 & 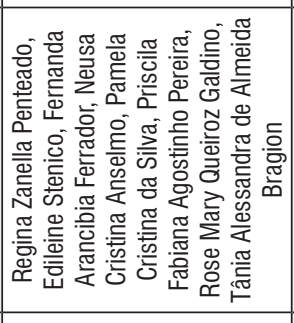 & 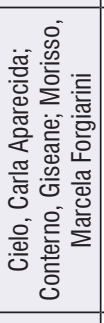 & 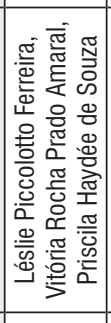 & 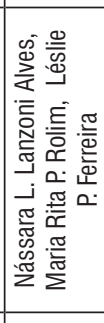 \\
\hline 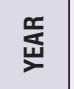 & 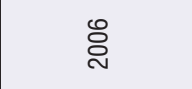 & 今్ & 命 & 怘 & 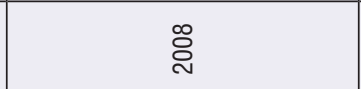 & 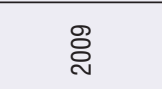 & ฉి & : & 을 & 商 \\
\hline
\end{tabular}




\begin{tabular}{|c|c|c|c|c|c|c|c|c|c|c|c|c|c|}
\hline 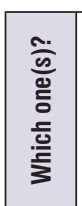 & & & & 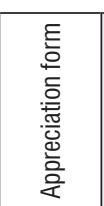 & & & & & 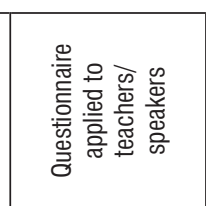 & & 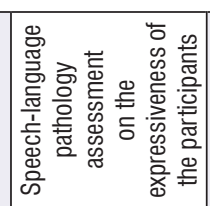 & & \\
\hline 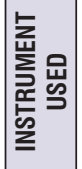 & 2 & $\stackrel{2}{2}$ & 2 & $\stackrel{\mathscr{J}}{x}$ & $\stackrel{2}{2}$ & 2 & $\stackrel{2}{2}$ & $\stackrel{2}{2}$ & $\stackrel{\mathscr{J}}{=}$ & 2 & $\stackrel{\mathscr{J}}{x}$ & $\stackrel{2}{2}$ & $\stackrel{2}{2}$ \\
\hline 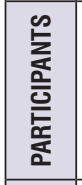 & $\frac{\text { 壹 }}{4}$ & $\frac{\frac{\infty}{\underline{7}}}{\frac{\bar{q}}{4}}$ & $\frac{\frac{\infty}{3}}{\frac{\bar{z}}{4}}$ & $\frac{\infty}{\frac{3}{4}}$ & $\frac{\frac{9}{7}}{\frac{\bar{z}}{\alpha}}$ & $\frac{\infty}{\frac{3}{4}}$ & $\frac{\frac{9}{3}}{\frac{\bar{z}}{4}}$ & $\frac{\infty}{\frac{1}{\bar{c}}}$ & 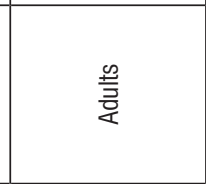 & $\frac{2}{\frac{2}{2}}$ & 䍘 & $\frac{\frac{\infty}{\underline{z}}}{\frac{\bar{z}}{\alpha}}$ & $\frac{\text { 号 }}{\frac{\bar{z}}{4}}$ \\
\hline $\begin{array}{l}\text { zo } \\
\text { 点 } \\
\text { 点 }\end{array}$ & 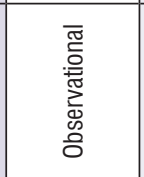 & 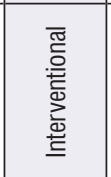 & 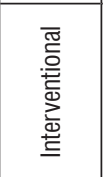 & 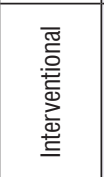 & 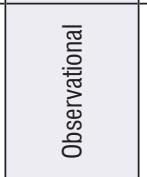 & 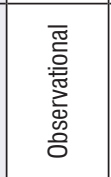 & 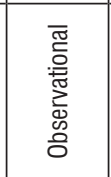 & 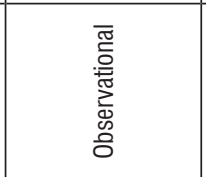 & 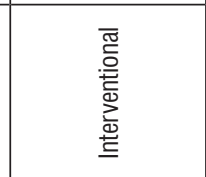 & 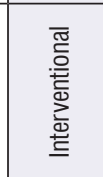 & 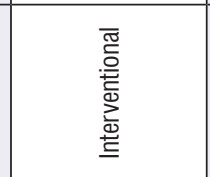 & 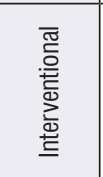 & 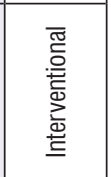 \\
\hline 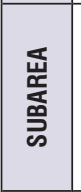 & 苂 & 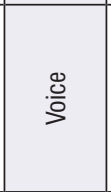 & 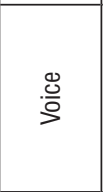 & 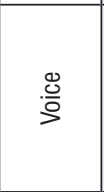 & 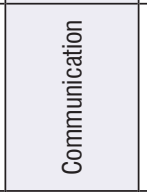 & 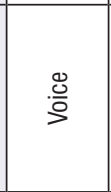 & 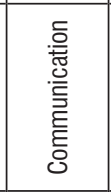 & $\stackrel{\Perp}{\stackrel{\circ}{\circ}}$ & $\stackrel{\mathscr{O}}{\frac{O}{3}}$ & 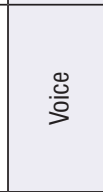 & $\stackrel{\ddot{\circ}}{\stackrel{\circ}{\circ}}$ & $\stackrel{\circ}{\circ}$ & $\stackrel{\ddot{\circ}}{\stackrel{\circ}{\circ}}$ \\
\hline 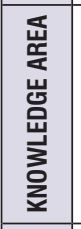 & 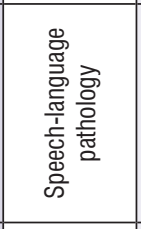 & 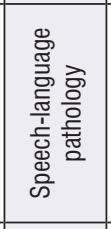 & 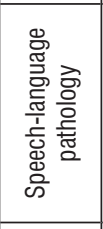 & 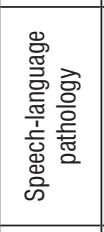 & 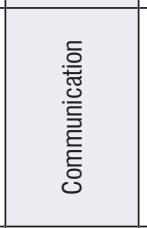 & 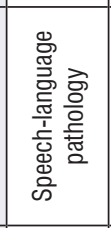 & $\begin{array}{l}\text { 흠 } \\
\text { 을 } \\
\text { 홍 }\end{array}$ & 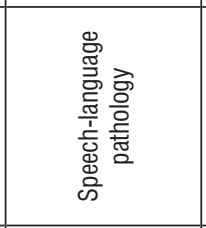 & 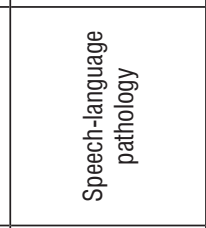 & 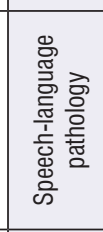 & 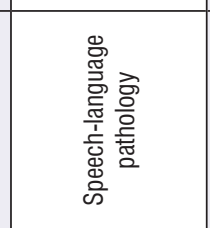 & 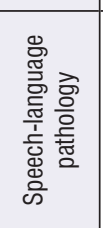 & $\begin{array}{l}\text { 趸 } \\
\text { 竞 }\end{array}$ \\
\hline 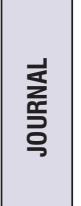 & 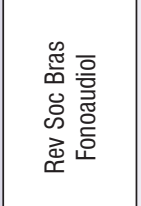 & 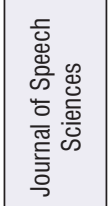 & 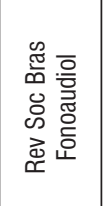 & 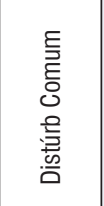 & 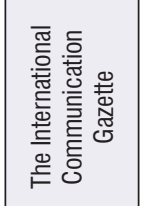 & 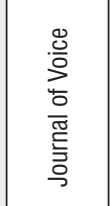 & 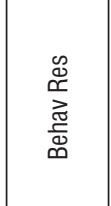 & $\begin{array}{l}\text { 몬 } \\
\text { ô }\end{array}$ & 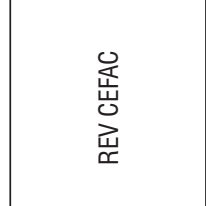 & 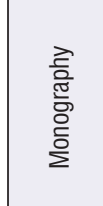 & 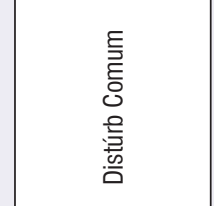 & 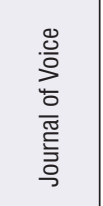 & 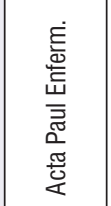 \\
\hline $\begin{array}{l}\text { zo } \\
\text { 을 } \\
\text { 点 } \\
\underline{\underline{\underline{p}}}\end{array}$ & 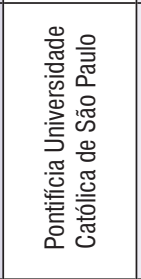 & 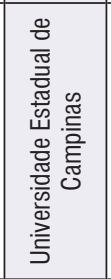 & 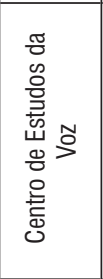 & 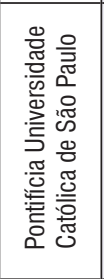 & 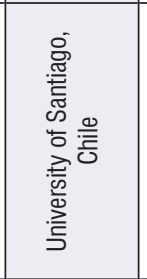 & 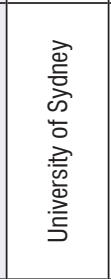 & 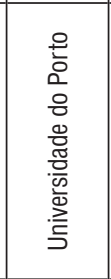 & 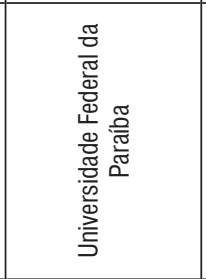 & 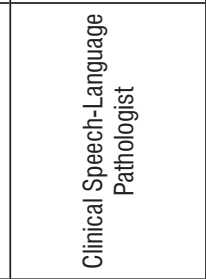 & 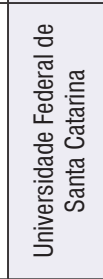 & 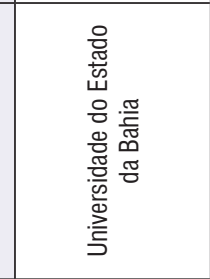 & 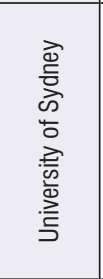 & 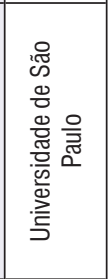 \\
\hline 岸 & 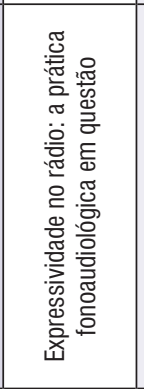 & 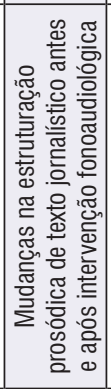 & 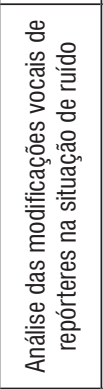 & 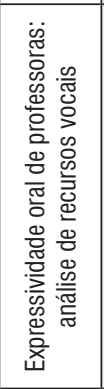 & 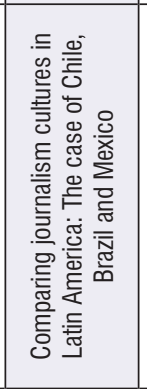 & 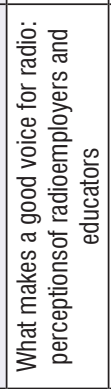 & 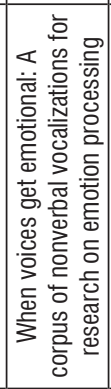 & 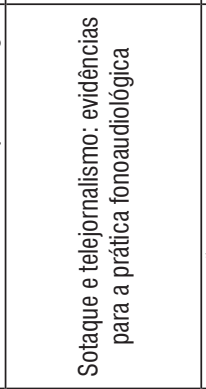 & 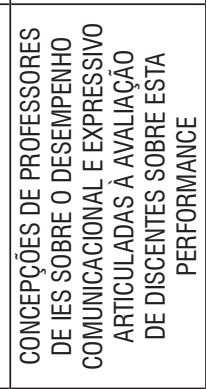 & 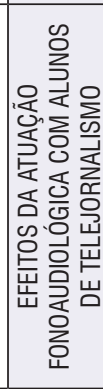 & 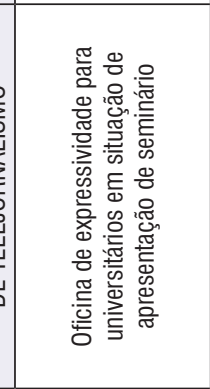 & 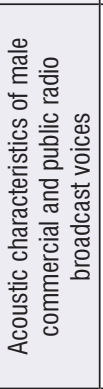 & 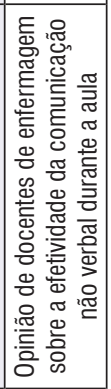 \\
\hline 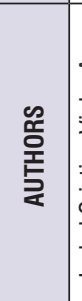 & 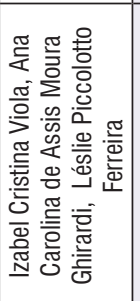 & 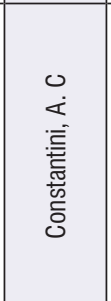 & 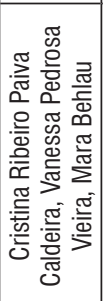 & 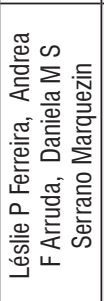 & 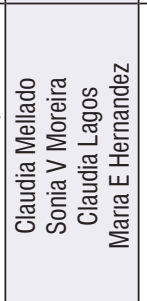 & 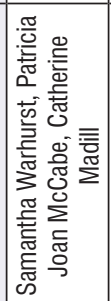 & 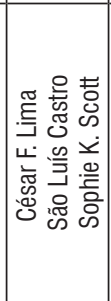 & 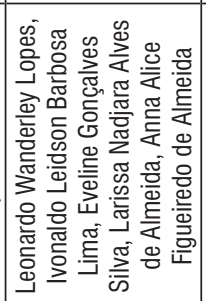 & 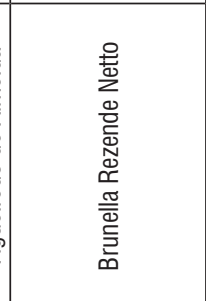 & 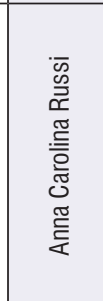 & 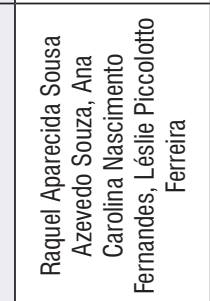 & 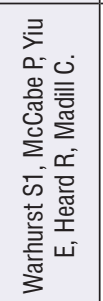 & 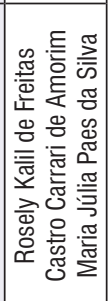 \\
\hline 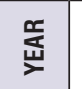 & $\stackrel{\bar{D}}{\text { ¿ }}$ & స్ & 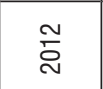 & స్ & స̃ & 芩 & ì & $\stackrel{m}{\stackrel{n}{2}}$ & $\stackrel{m}{\stackrel{m}{~}}$ & $\stackrel{m}{\stackrel{n}{n}}$ & 克 & 克 & $\stackrel{\nabla}{\sim}$ \\
\hline
\end{tabular}




\begin{tabular}{|c|c|c|c|c|c|c|c|c|}
\hline 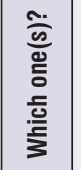 & 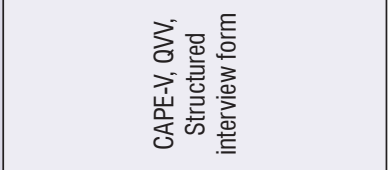 & & & & & & & 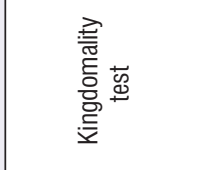 \\
\hline 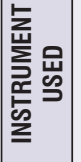 & $\stackrel{\mathscr{J}}{=}$ & $\stackrel{2}{z}$ & $\stackrel{2}{2}$ & 2 & $\stackrel{2}{2}$ & $\stackrel{0}{2}$ & $\stackrel{0}{2}$ & $\stackrel{\mathscr{D}}{\not}$ \\
\hline 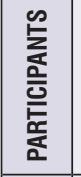 & 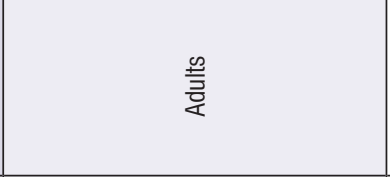 & - & $\frac{\text { 号 }}{\frac{\bar{z}}{\alpha}}$ & $\frac{\underline{\underline{T}}}{\frac{\bar{z}}{\alpha}}$ & $\frac{0}{\frac{5}{z}}$ & $\frac{\text { 号 }}{\frac{3}{4}}$ & $\frac{0}{\frac{1}{2}}$ & $\frac{\frac{\infty}{7}}{\frac{\bar{z}}{4}}$ \\
\hline 毫竞 & 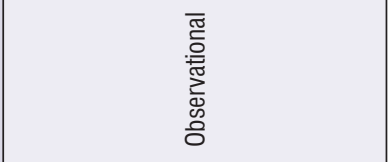 & 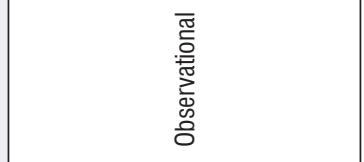 & 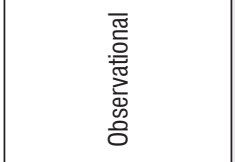 & 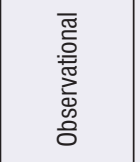 & 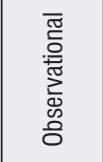 & 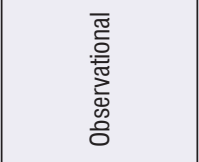 & 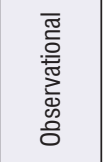 & 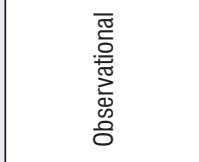 \\
\hline 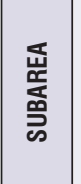 & 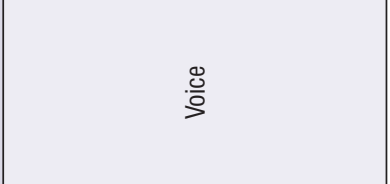 & $\stackrel{\mathscr{O}}{\stackrel{.}{3}}$ & $\stackrel{\mathscr{O}}{\frac{\mathscr{O}}{5}}$ & 苂 & 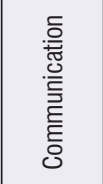 & $\stackrel{\mathscr{O}}{\bar{\rho}}$ & 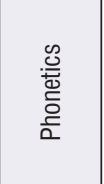 & 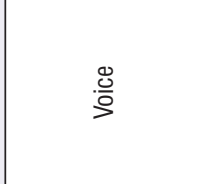 \\
\hline 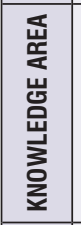 & 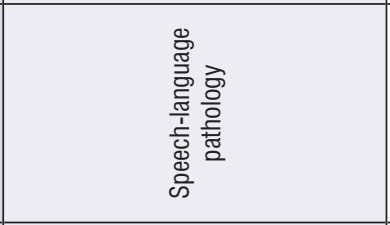 & 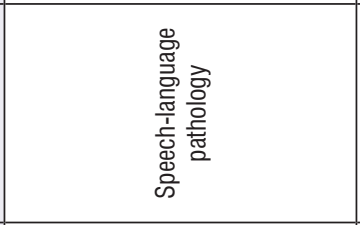 & 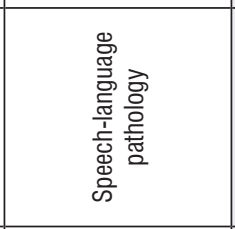 & 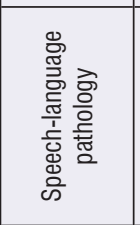 & 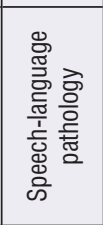 & 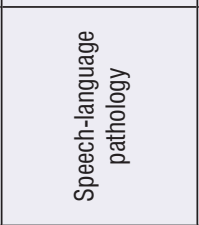 & 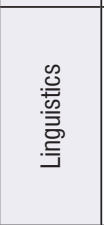 & 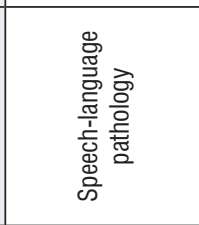 \\
\hline 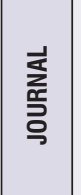 & 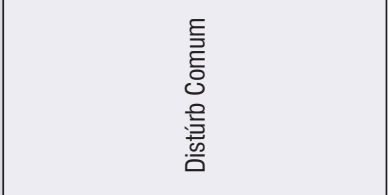 & 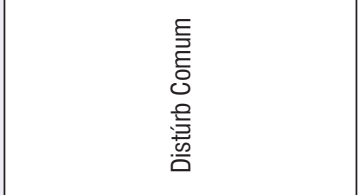 & 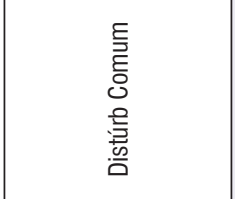 & $\begin{array}{l}\text { 营 } \\
\text { 岕 } \\
\text { 㟧 }\end{array}$ & 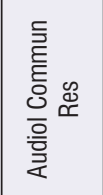 & 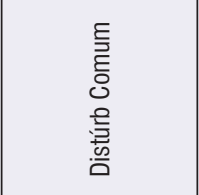 & 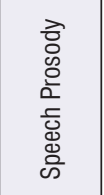 & $\begin{array}{l}\text { ợ } \\
\text { 엉 }\end{array}$ \\
\hline $\mid \begin{array}{l}\text { zo } \\
\text { 흘 } \\
\text { 点 } \\
\underline{\underline{s}}\end{array}$ & 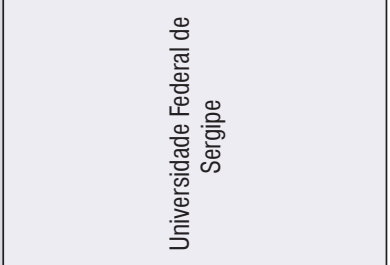 & 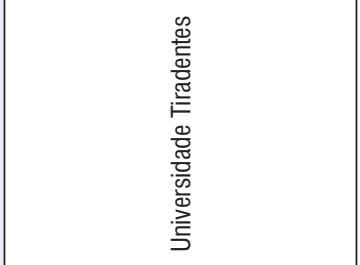 & 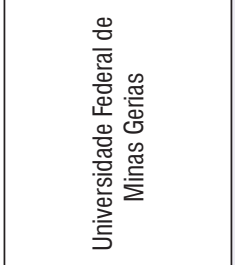 & 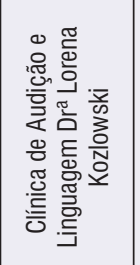 & 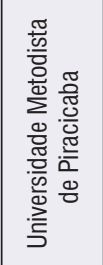 & 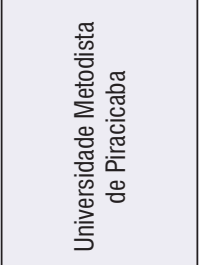 & 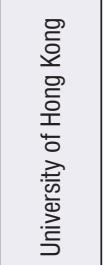 & 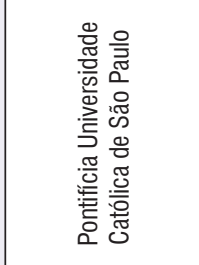 \\
\hline 崖 & 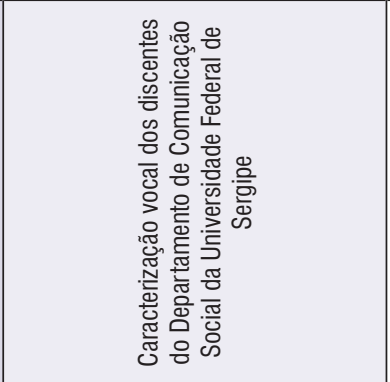 & 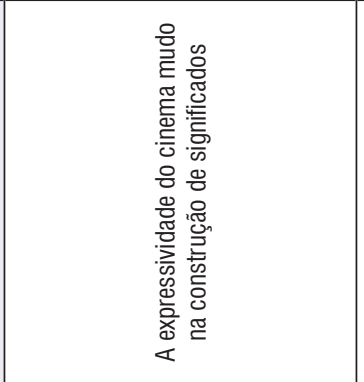 & 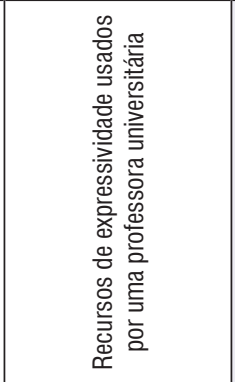 & 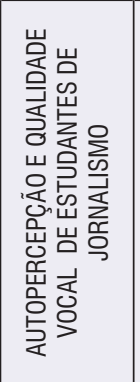 & 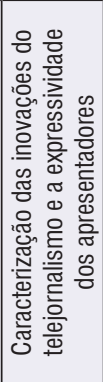 & 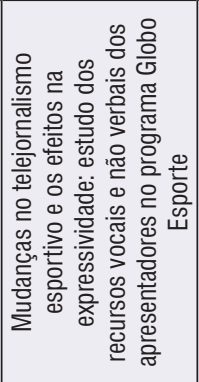 & 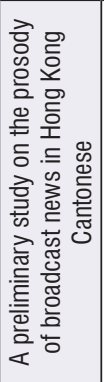 & 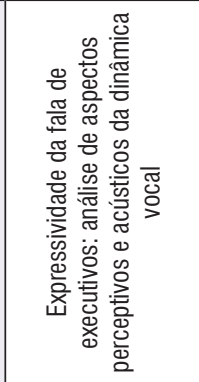 \\
\hline 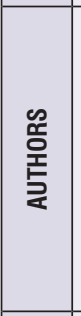 & 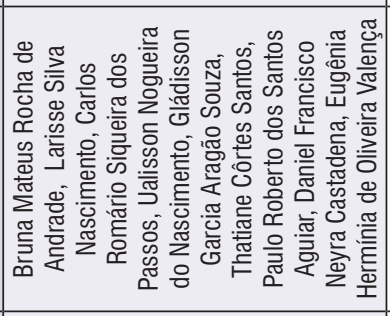 & 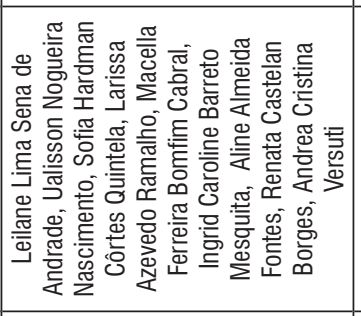 & 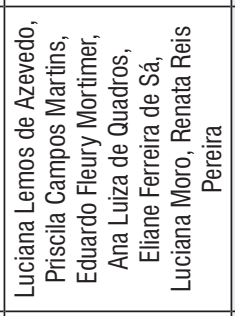 & 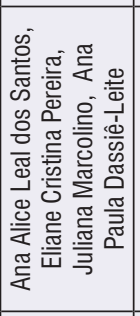 & 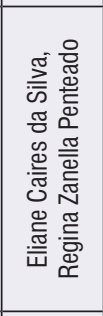 & 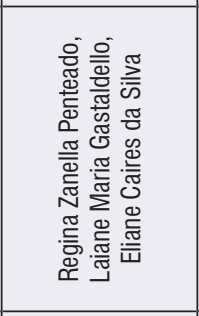 & 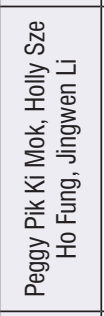 & 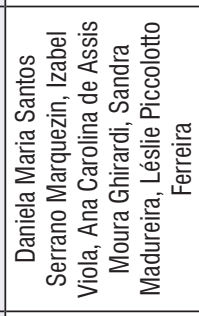 \\
\hline 妥 & 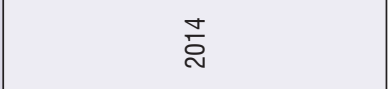 & 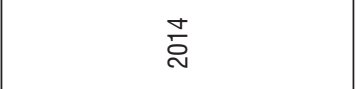 & 志 & 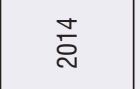 & $\stackrel{\nabla}{\stackrel{D}{2}}$ & 志 & 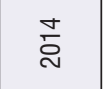 & $\overline{\text { กิ }}$ \\
\hline
\end{tabular}




\begin{tabular}{|c|c|c|c|c|c|c|c|c|}
\hline 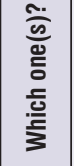 & & & & & 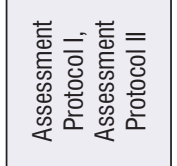 & & 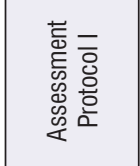 & \\
\hline 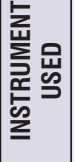 & $\stackrel{\mathscr{C}}{\check{0}}$ & 2 & $\stackrel{\mathscr{J}}{=}$ & $\stackrel{2}{2}$ & $\stackrel{\mathscr{J}}{=}$ & $\stackrel{2}{2}$ & $\stackrel{\mathscr{B}}{\check{0}}$ & $\stackrel{2}{2}$ \\
\hline 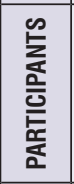 & $\frac{\infty}{\frac{w}{z}}$ & 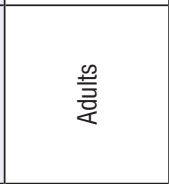 & $\frac{\frac{\infty}{5}}{\frac{3}{4}}$ & $\frac{\frac{\infty}{5}}{\frac{\bar{z}}{x}}$ & 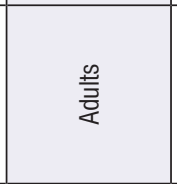 & $\frac{\frac{0}{5}}{\frac{\bar{z}}{\alpha}}$ & $\frac{\infty}{\frac{w}{z}}$ & $\frac{\frac{D}{5}}{\frac{\bar{z}}{x}}$ \\
\hline 容 & 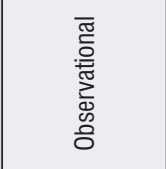 & 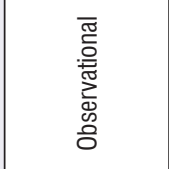 & 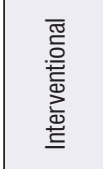 & 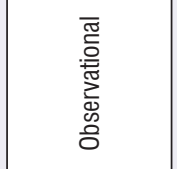 & 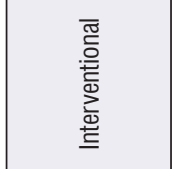 & 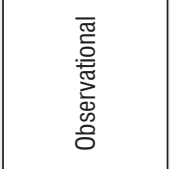 & 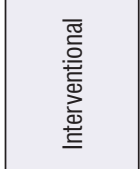 & 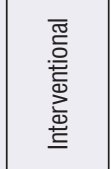 \\
\hline 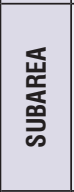 & 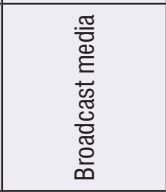 & 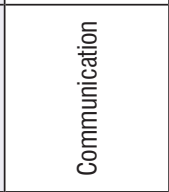 & 芦 & 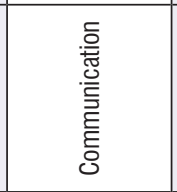 & 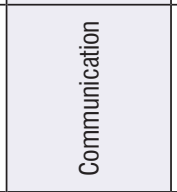 & 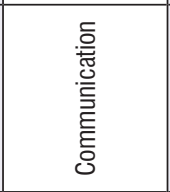 & 苂 & $\stackrel{.0}{\frac{.}{5}}$ \\
\hline 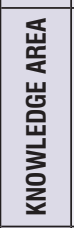 & 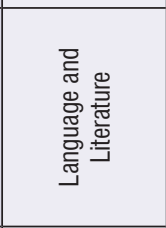 & 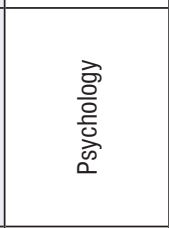 & 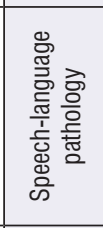 & 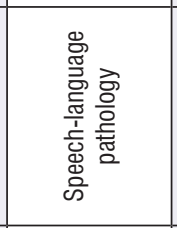 & 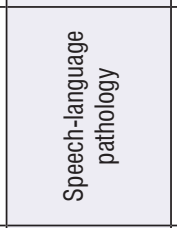 & 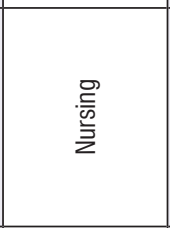 & 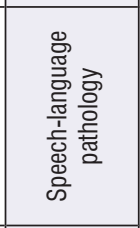 & 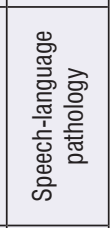 \\
\hline 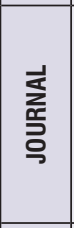 & 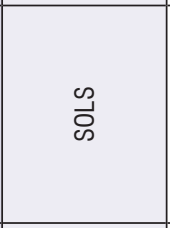 & 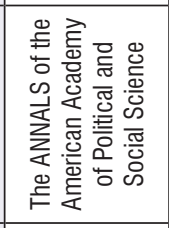 & 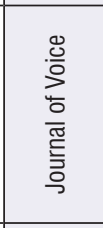 & 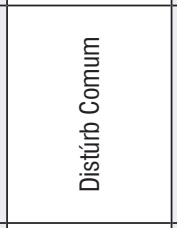 & 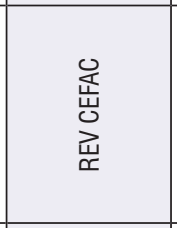 & 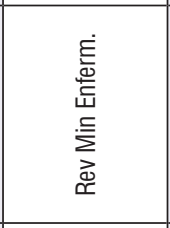 & 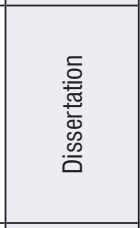 & $\begin{array}{l}\text { 崖 } \\
\text { 嵌 }\end{array}$ \\
\hline $\begin{array}{l}\text { zo } \\
\text { 点 } \\
\text { 点 } \\
\underline{\underline{s}}\end{array}$ & 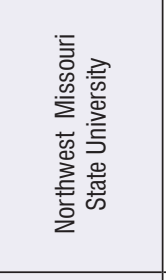 & 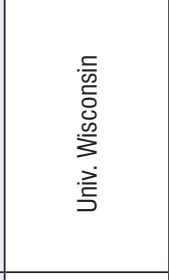 & 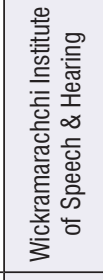 & 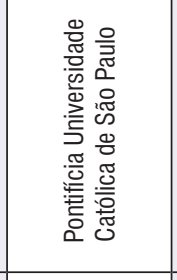 & 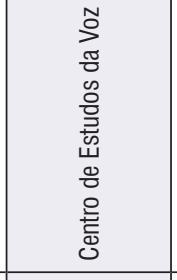 & 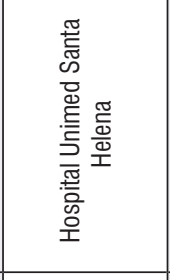 & 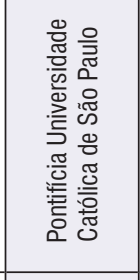 & 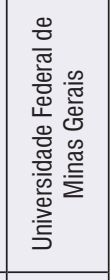 \\
\hline 岸 & 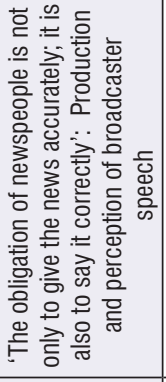 & 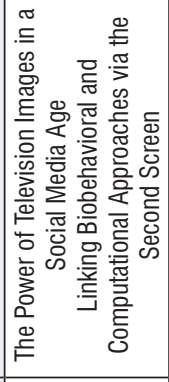 & 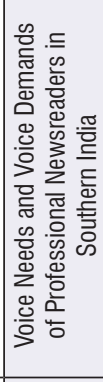 & 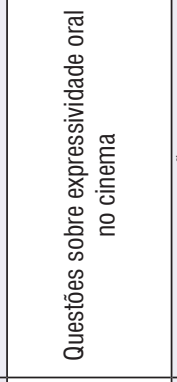 & 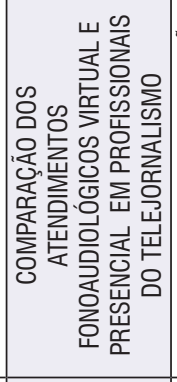 & 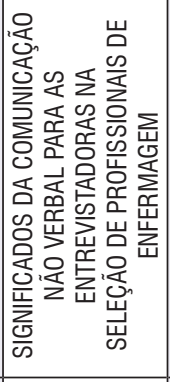 & 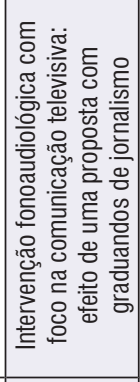 & 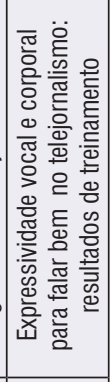 \\
\hline 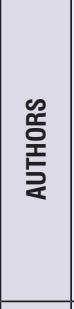 & 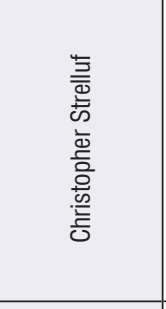 & 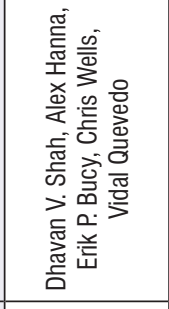 & 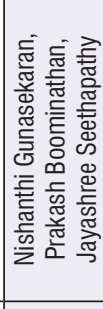 & 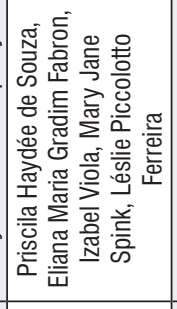 & 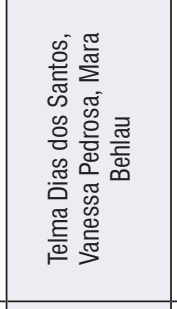 & 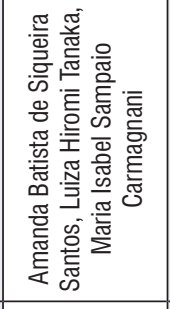 & 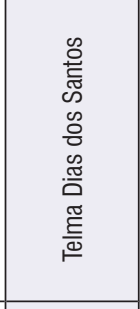 & 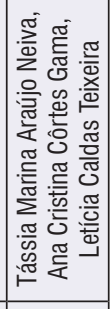 \\
\hline 妥 & $\stackrel{\text { D. }}{\stackrel{N}{N}}$ & 몸 & $\stackrel{\circ}{\stackrel{2}{D}}$ & $\stackrel{\text { 모 }}{\stackrel{2}{n}}$ & กิ & $\stackrel{\circ}{\stackrel{2}{\circ}}$ & ஸे. & 을 \\
\hline
\end{tabular}

